\title{
Psychological stress and cancer
}

\author{
Nak Kyun Soung and Bo Yeon Kim ${ }^{*}$ (D)
}

\begin{abstract}
Psychological or psychosocial stress has been emerging as one of the key factors associated with cancer initiation, growth, and metastasis. Accumulating data, however, has mainly focused on cancer progression due to the inconsistent results of cancer etiology caused by emotional stress. Depression is closely linked to stress and induces hypothalamic-pituitary-adrenal (HPA) axis activation as well as sympathetic nervous system (SNS) down to immune cell surveillance. This review briefly describes the activation of neuroendocrine system by psychological stress/ depression and its effect on cancer occurrence and metastasis, which may be useful for the design of new cancer treatments.
\end{abstract}

Keywords: Stress, Depression, Cancer, HPA, SNS

\section{Review}

\section{Introduction}

Distress or depression can lead to a poor repair of damaged DNA, an abnormal chromatid exchange, and reduced apoptotic activity. Accordingly, psychological or behavioral factors and stress can influence many physiological and pathological disease outcomes including cancer (Andersen et al. 1994, Andersen et al. 1998; Bovbjerg 1991; Levy et al. 1985, 1987; Spiegel and Kato 1996), as carefully examined for the last three decades. Research over the past 30 years in the field of psychoneuroimmunology (PNI) and multiple clinical and epidemiological studies have given much contribution to the understanding of the effect of psychological stress on human diseases, with particular emphasis on cancer related to suppressed immune responses to tumors and stress-induced alterations in the tumor microenvironment. Subjects who are immunosuppressed either through pharmacological means or via immunodeficiency diseases have an increased risk of cancer (Herberman and Ortaldo 1981; Cohen and Rabin 1998). Moreover, tumor growth, progression, and metastasis have also been correlated with stress, anxiety, depression, and numerous other psychological and behavioral abnormalities (Lillberg et al. 2003; Spiegel and Giese-Davis 2003). In vivo mouse models of stress have made a significant progress in determining the mechanisms of stress-induced alterations in inflammatory immune responses; a social disruption (SDR) stress mouse

\footnotetext{
* Correspondence: bykim@kribb.re.kr

Incurable Diseases Therapeutics Research Center(WCI), Bio-Therapeutics

Research Institute, Korea Research Institute of Bioscience \& Biotechnology,
} Yancheongri, Ochang 28116, Korea model of repeated social defeat has linked stress to triggering the generation, egress, and trafficking of immature, inflammatory myeloid-derived cells that are glucocorticoid (GC) insensitive (Curry et al. 2010; Engler et al. 2004a, 2005) and produce high levels of IL- 6 and other inflammatory cytokines and chemokines (Powell et al. 2009; Stark et al. 2002; Wohleb et al. 2011). These stress-induced changes in the sympathetic nervous system (SNS) led to significant immune and prolonged anxiety-like behavior changes (Wohleb et al. 2011; Bailey et al. 2007, 2009a, 2009b, Dong-Newsom et al. 2010; Kinsey et al. 2007; Mays et al. 2010, 2012; Powell et al. 2011), and could be reversed by the blockade of sympathetic signaling prior to stressor exposure (Wohleb et al. 2011). Studies involving both animals and humans suggest that natural killer (NK) cells are particularly important in the elimination of metastatic tumor cells (Whiteside and Herberman 1989; Page et al. 1994). In perspective, SDR and other knockout mouse models of stress can be ideally used to explore the treatments and therapeutics against stressinduced carcinogenesis. This short review focuses on the effects of psychological stress on cancer etiology and progression in relation to immune functions.

\section{Stress and immune response}

Data from prospective studies suggest that even commonplace stressful events are associated with transient decrements in a number of immunological functions, as manifested by significant declines in NK cell activity and interferon production in medical students on the day of final examinations (Glaster et al. 1986; Kiecolt-Glaser

\section{实 Springer}


et al. 1984, Kiecolt-Glaser et al. 1986; Glaser et al. 1987; Herberman et al. 1982). In contrast, significant immune enhancement via a behavioral intervention could be detected in 45 older adults who were randomly assigned to relaxation training, social contract, or no intervention (Kiecolt-Glaser et al. 1985a, b). Several subsequent studies have also suggested a link between personal relationships and NK cell cytotoxicity, consistent with the broad literature on social support and health (Uchino et al. 1996), bereavement or loneliness (Kiecolt-Glaser et al. 1984; Irwin et al. 1988) and NK cell activity, negative mind or hostility during discussion (Kiecolt-Glaser et al. 1993), and AD patient's caregivers and neuropeptide levels (Irwin et al. 1991). A follow-up study using cell preparations enriched for NK cells (approximately $90 \%$ ) replicated the previously observed group differences between caregivers (current and former) and controls (Esterling et al. 1996). In addition, higher levels of social support were associated with heightened NK cell responses to cytokines, independent of the level of depression.

From the data obtained to date, it is clear that stress can alter a potentially important defense mechanism against malignant diseases; stress can not only alter NK cell activity in normal populations but can also depress the ability of NK cells to respond to the cytokines necessary for effective cell killing of appropriate tumor or virally infected cells (Glaser and Kiecolt-Glaser 1994). Immune cells like inflammatory macrophages, NK cells, and cytotoxic T cells (CTL) can be found in the core of primary tumors and within the invasive and metastatic tumor microenvironments Hanahan and Weinberg 2011). NK cells and CTL are known to be regulated by stress, influencing tumor progression through association with major histocompatibility complex (MHC) class I expression, interferon (IFN) production and release of apoptotic protein perforins, granzymes A and B, and FasL (Bubenik 2004).

Chronic inflammation has been linked to several types of cancers; a study of breast cancer patients 3 years post-treatment showed elevated levels of stress-inducible acute phase proteins correlating with an increase in morbidity and mortality in the experimental cohort (Pierce et al. 2009), and circulating levels of IL-6 have been reported as a prognostic indicator of survival and metastasis in human cancers (Chung and Chang 2003; Salgado et al. 2003). Evidence linking chronic inflammation and SNS activation to cancer progression provides insights into how cancer-related genes (e.g., IL-6) modulate the effects of stress on cancer.

Stress has also been shown to modulate the inhibitory receptors, potentially mediating the effect of NK and CTL on viral replication (Hunzeker et al. 2004; Tseng et al. 2005) and cancer progression Andersen et al. 1998). Stress, however, may also cause beneficial effects on NK activity by enhancing migration and function Schedlowski et al. 1993), increasing NK cell trafficking from the bone marrow, into the blood and peripheral organs (Engler et al. 2004b; Kradin et al. 2001). Enhanced generation of primary and memory CTL in response to a stressful infection was reported to increase inflammatory and anti-viral cytokine secretion and enhance killing (Mays et al. 2010, 2012).

\section{Stress and carcinogenesis}

Most carcinogens are expected to damage the cellular DNA, producing mutant cells (Setlow 1978). However, defense mechanisms in the body exist, activating enzyme systems that destroy chemical carcinogens and processes for identifying and repairing damaged DNA and the destruction of mutant or unrepaired DNA by the immune system Fox 1978). When these processes are not in the correct work, the resulting faulty DNA might be associated with an increased risk of cancer (Setlow 1978). Stress was suggested to be able to alter the DNA repair process; in a study exploring the effect of carcinogen dimethylnitrosamine on the component of the DNA repair system, the levels of an important DNA repair enzyme methyltransferase were significantly lowered in stressed animals' splenic lymphocytes compared with control rats (Glaser et al. 1985). It was also suggested that stress might have affected carcinogenesis through alterations in DNA repair and that sister chromatid exchange (SCE) could occur through different types of stress in bone marrow cells (Glaser et al. 1985; Kiecolt-Glaser et al. 1985a, b; Fischman and Kelly 1987; Dhillon and Dhillon 1998; Li et al. 1989).

The carcinogenic agents, tumor-promoting phorbol esters, were shown to block ionizing radiation-induced apoptosis in vitro (Kanter et al. 1984; Tomei et al. 1988). Low concentrations of 12-0-tetradeconoyl-phorbol-13acetate (TPA) specifically blocked apoptosis in response to ionizing radiation in peripheral blood lymphocytes (PBLs) (Tomei et al. 1990). Another study showed that PBLs obtained from medical students at the time of examination survived treatment with TPA and radiation. Thus, stress could induce changes in apoptosis in the body, rendering the survived cells with abnormal levels of DNA to increase the risk of the development of malignant cells.

Although the precise mechanism linking the physiological changes induced by carcinogenic stress and the observed changes in DNA repair, apoptosis, and sister chromatid exchange is not yet known, given the activation of the hypothalamic-adrenal-pituitary (HPA) axis and the autonomic nervous system by stress, stress hormones appear to mediate these responses and are targets for the development of therapeutics against stressinduced carcinogenesis. 


\section{Stress effect on cancer}

With great interest in psychological factors that could affect the cancer etiology and progression, earlier studies suggested links between personality types and cancer etiology. Methodological problems in many of these studies, however, significantly hampered the interpretation of the links, and a great deal of important work in this area over the past three decades tremendously accelerated demonstration of potential effects of stress on tumor metastasis, the tumor microenvironment, and regulation of cell growth.

The data until 1997 was too inconsistent to find a relationship between stressor exposure and cancer etiology (Reiche et al. 2004; Antoni et al. 2006). In addition, depression and other psychological factors were not consistent predictors of cancer etiology (Antoni et al. 2006). Thus, it would only be detectable if considered in conjunction with known risk factors such as genetics, gender, site of cancer, age, and health behaviors, such as smoking.

In contrast to cancer etiology, animal studies and in vitro work have contributed to the researches on human, uncovering the molecular mechanisms that would allow stress and psychological factors to affect tumor progression, at least with certain forms of cancer. Regarding the relationship between stress and immune function in cancer patients, including in the tumor microenvironment, TNF-a, known to be associated with tumor regression and survival, was decreased in breast cancer patients with social disruption (Marucha et al. 2005). Reduced DNA repair in those with psychiatric illness was also found (Reiche et al. 2004). The data suggested that cancer-relevant process may be amenable to influence by psychological factors. Starting from the animal studies demonstrating the effects of stressors such as restraint, forced swim, and social isolation on tumor growth or metastasis (Reiche et al. 2004), a few researches may have clinical utility in humans for suppression of tumor metastasis in that a product could cause NK cells to be partially resistant to suppression by agents that increase cAMP. Direct researches with human cancer cell lines have also been fruitful, identifying the potential pathways from stress to tumor cell development. Noradrenaline (NE) was found to promote metastatic processes in vitro, acting on the b-adrenergic receptor-cyclic AMP protein kinase A pathway in ovarian cancer cell lines, which could be antagonized by a beta blocker. HPA axis was also demonstrated to play a role in tumor initiation, growth, and survival by effecting on apoptosis of lymphocytes, survival genes that protect cancer cells from chemotherapy effects, oncogenic viruses, and immune responses to tumors (Antoni et al. 2006).

Stressful life experiences, depression, and other psychiatric disorders have been shown to disrupt circadian rhythms of the HPA, and these stress-related alterations in hormonal and immunological circadian rhythms was also proposed to play a role in cancer progression (Sephton et al. 2003). Abnormal circadian rhythms were observed in individuals at high risk for breast cancer and predicting cancer outcomes, decreasing the number and activity of NK cells and increasing early mortality up to 7 years after assessment. These HPA alterations were associated with poor sleep, prior marital disruption, and mutations in circadian clock genes that may be at increased risk for tumor development and shortened survival.

Collectively, thorough exploitation of the signaling pathway from the neuroendocrine system to immune cancer may give a chance of therapeutics development in this sense.

\section{Animal model studies}

The neuroendocrine and sympathetic-mediated regulation of immune function and the changes in immune status in relation to tumor growth and progression and cancer biology have been provided by the animal models of stress after exposure to a variety of different stressors. A mouse model of cancer socially isolated showed decreased macrophage activity and increased tumor growth (Palermo-Neto et al. 2003), and similar results could be obtained demonstrating a decreased number of immune cells including suppressor $\mathrm{T}$ cells and reduced cytokine/ chemokine secretion in breast cancer, and skin and squamous cell carcinoma models following exposure to stress (Saul et al. 2005; Steplewski et al. 1985). b-Adrenergic agonists and its antagonists showed increased metastasis of breast cancer to lung and amelioration of stress-associated increase in lung metastasis, respectively (Sloan et al. 2010) but without effect on the tumor size itself. The data identified infiltrating macrophage as a key intermediate in stress-induced tumor cell metastasis, demonstrating the important relationship between behavioral stress, immune system, and disease outcomes. Moreover, although the effect of psychosocial stress on cancer is largely unexplored, social disruption (SDR) stress animal model has been effective in predicting its impact on disease and behavior, including the response to influenza viral infection (Mays et al. 2010, 2012; Powell et al. 2011) and pronounced anxiety-like behavior in mice exposed to SDR (Curry et al. 2010; Engler et al. 2005; Wohleb et al. 2011; Kinsey et al. 2007; Avitsur et al. 2002). Stress itself could induce significant lung inflammation in mice experiencing SDR (Curry et al. 2010).

Tumor progression and metastasis are closely associated with stress through inflammatory cells, including myeloid cells like macrophages and neutrophils. These normal immune cells are typically present within and along the margin of invasive and metastatic tumors, and produce pro-angiogenic factors, pro-inflammatory cytokines, and/or pro-invasive matrix degrading enzymes like matrix metalloproteinases (MMPs) (Hanahan and 
Weinberg 2011). Stressor or exposure to stress hormone enhances the production of MMPs, which is required for both local and distant tumor spread (Sood et al. 2006; Yang et al. 2006) as illustrated in ovarian cancer cells treated with stress-levels of NE (Sood et al. 2006). In addition to MMPs, IL-6, a circulating biomarker indicative of immune changes in tissue and circulation, can be produced within the tumor microenvironment (Kossakowska et al. 1999) by both tumor cells and macrophages that infiltrate the tumor site. Secreted by stress in models of repeated social defeat, increased plasma IL-6 levels is a hallmark of the physiologic response to a stressor. Stressed-primed cells secrete cancer-modulating cytokines including IL-6, and have an increased capacity for survival and migration. Social defeat-induced activation of the HPA axis and SNS and the resultant immune alterations will likely impact factors that lead to the morbidity and mortality associated with cancer. This may include but is not limited to enhanced inflammatory mediators and immune cells in the tumor microenvironment, increased tumor growth, increased migration and invasion of tumor cells, and enhanced angiogenesis. The possible interaction of stress-induced cytokine production with tumor initiation, however, needs to be elucidated with more accumulating evidence.

\section{Cancer treatment}

Despite investigation linking the relationship between psychosocial stressors and tumor development or progression facing many obvious difficulties including the stage of disease and a number of side-effects associated with the cancer treatments (Andersen et al. 1994), a number of observations showed that stress-reducing interventions could improve immune function (Kiecolt-Glaser and Glaser 1992; Fawzy et al. 1990, 1993). Patients with stage I or II malignant melanoma, not having received any treatment after surgical excision of the cancer, showed significant relationship of reduced psychological distress with increased percent and cytotoxicity of NK cells compared with control groups. A 6-year follow-up study of these patients showed a trend towards significantly lowered recurrence and mortality rate in the intervention patients compared to control group. Consistent results could also be found in the intervention study showing that continued therapy with self-hypnosis extended survival time in women with metastatic breast cancer (Spiegel et al. 1989). Although it is not known if these data reflect immunological alterations that influenced the course of the cancer, and a number of other interpretations are plausible, behavioral differences could have contributed to the observed outcomes. Other data from breast cancer patients consistently linked NK cell activity with social support, associating higher NK cell activity with the perception of high-quality emotional or social support from a spouse or the patient's physician (Levy et al. 1990).
Recently, our group discovered a new function of a protein involved in protein degradation and tumorigenesis through autophagy. Knockout model mouse of the protein showed possible link of psychological stress to protein quality control, suggesting its extension to cancer. Further study with these animal models would be expected to uncover novel target genes for the treatment of cancer.

\section{Conclusions}

Studies have suggested that psychological or behavioral factors may influence the incidence or progression of cancer through psychosocial influences on immune function. In this respect, physiological pathways and mechanisms for bio-behavioral factors and cancer progression was reviewed (Lutgendorf et al. 2011). In addition, molecular study with telomerase activity associated telomere length with environmental and psychological stress (Epel et al. 2010; Romano et al. 2013). A result of interest, however, was recently published demonstrating that the effects of personality traits and depression on cancer risk and survival appear to be extremely as small as the data obtained from prospective cohort studies in population-based and clinical databases Nakaya 2014). Despite this database result, the possibility and abundance of evidence showing that psychological interventions and social support may enhance immune function and survival among cancer patients clearly merits further exploration, particularly for the treatment of cancer associated with stress and depression. Although not yet clearly defined, cancer initiation can also be affected by psychosocial behavior and psychological stress. Identification of the genes affected by those emotional changes including depression and stress is expected to shed light on the discovery of a new family of anticancer drugs related with psychological disorder or stress.

\section{Competing interests}

The authors declare that they have no competing interests.

\section{Authors' contributions}

NKS collected data and information relevant to psychological stress and cancer and BYK drafted the manuscript. Both authors read and approved the final manuscript.

\section{Acknowledgement}

This work was supported by the World Class Institute (WCI) Program (WCI 2009-002), the Bio and Medical Technology Development Program (NRF-2014M3A9B5073938) of the National Research Foundation (NRF) funded by the Ministry of Science, ICT and Future Planning (MSIP) of Korea, and also by the KRIBB Research Initiative Program.

Received: 30 September 2015 Accepted: 5 October 2015

Published online: 03 November 2015

\section{References}

Andersen BL, Farrar WB, Golden-Kretuz D, Kutz LA, MacCallum R, Courtney ME, et al. Stress and immune responses after surgical treatment for regional breast cancer. J Natl Cancer Inst. 1998;90:30-6. 
Andersen BL, Kielcolt-Glaser JK, Glaser RA. Biobehavioural model of cancer stress and disease course. Am Psychol. 1994;49:389-404.

Antoni MH, Lutgendorf SK, Cole SW, Dhabhar FS, Sephton SE, McDonald PG, et al. The influence of bio-behavioural factors on tumour biology: pathways and mechanisms. Nat. Rev. Cancer. 2006;6:240-8.

Avitsur R, Stark J, Dhabhar FS, Sheridan JF. Social stress alters splenocyte phenotype and function. J Neuroimmunol. 2002;132:66-71.

Bailey MT, Engler H, Powell ND, Padgett DA, Sheridan JF. Repeated social defeat increases the bactericidal activity of splenic macrophages through a Toll-like receptor-dependent pathway. Am J Physiol Regul Integr Comp Physiol. 2007;293:R1180-90

Bailey MT, Kierstein S, Sharma S, Spaits M, Kinsey SG, Tliba O, et al. Social stress enhances allergen-induced airway inflammation in mice and inhibits corticosteroid responsiveness of cytokine production. J Immunol. 2009a;182:7888-96.

Bailey MT, Kinsey SG, Padgett DA, Sheridan JF, Leblebicioglu B. Social stress enhances IL-1beta and TNF-alpha production by Porphyromonas gingivalis lipopolysaccharide-stimulated CD11b + cells. Physiol Behav. 2009b;98:351-8.

Bovbjerg DH. Psychoneuroimmunology: implications for oncology? Cancer. $1991 ; 67: 828-32$

Bubenik J. MHC class I down-regulation: tumour escape from immune surveillance? (review). Int J Oncol. 2004;25:487-91.

Chung YC, Chang YF. Serum interleukin-6 levels reflect the disease status of colorectal cancer. J Surg Oncol. 2003;83:222-6.

Cohen S, Rabin B. Psychologic stress, immunity, and cancer. J Natl Cancer Inst. 1998:90:3-4.

Curry JM, Hanke ML, Piper MG, Bailey MT, Bringardner BD, Sheridan JF, et al. Social disruption induces lung inflammation. Brain Behav Immun. 2010;24:394-402

Dhillon VS, Dhillon IK. Chromosome aberrations and sister chromatid exchange studies in patients with prostate cancer possible evidence of chromosome instability. Cancer Genet. 1998;100:143-7.

Dong-Newsom P, Powell ND, Bailey MT, Padgett DA, Sheridan JF. Repeated social stress enhances the innate immune response to a primary HSV- 1 infection in the cornea and trigeminal ganglia of Balb/c mice. Brain Behav Immun. 2010;24:273-80

Engler H, Bailey MT, Engler A, Sheridan JF. Effects of repeated social stress on leukocyte distribution in bone marrow, peripheral blood and spleen. J Neuroimmunol. 2004a;148:106-15.

Engler H, Dawils L, Hoves S, Kurth S, Stevenson JR, Schauenstein K, et al. Effects of social stress on blood leukocyte distribution: the role of alpha- and beta-adrenergic mechanisms. J Neuroimmunol. 2004b;156:153-62.

Engler H, Engler A, Bailey MT, Sheridan JF. Tissue-specific alterations in the glucocorticoid sensitivity of immune cells following repeated social defeat in mice. J Neuroimmunol. 2005;163:110-9.

Epel ES, Lin J, Dhabhar FS, Wolkowitz OM, Puterman E, Karan L, et al. Dynamics of telomerase activity in response to acute psychological stress. Brain Behav Immun. 2010;24:531-9.

Esterling BA, Kiecolt-Glaser JK, Glaser R. Psychosocial modulation of cytokineinduced natural killer cell activity in older adults. Psychosomat Med. 1996;58:264-72.

Fawzy FI, Fawzy NW, Hyun CS, Elashoff R, Guthrie D, Fahey JL, et al. Malignant melanoma: eVects of an early structured psychiatric intervention, coping and aVective state on recurrence and survival 6 years later. Arch Gen Psychiat. 1993:50:681-9.

Fawzy IF, Kemeny ME, Fawzy NW, Elashott R, Morton D, Cousins N, et al. A structured psychiatric intervention for cancer patients. Arch Gen Psychiat. 1990;47:729-35.

Fischman HK, Kelly DD. Sister chromatid exchanges induced by behavioural stress. Ann New York Acad Sci. 1987;496:426-35.

Fox $\mathrm{BH}$. Premorbid psychological factors as related to cancer incidence 1 . J Behav Med. 1978;1:45-133.

Glaser R, Kiecolt-Glaser JK. Handbook of human stress and immunity. San Diego: Academic Press; 1994.

Glaser R, Rice J, Sheridan J, Fertel R, Stout J, Speicher C, et al. Stress-related immune suppression: health implications. Brain Behav Immun. 1987:1:7-20.

Glaser R, Thorn BE, Tarr KL, Kiecolt-Glaser JK, d'Ambrosio SM. EVects of stress on methyltransferase synthesis: an important DNA repair enzyme. Health Psychol. 1985;4:403-12.
Glaster R, Rice J, Speicher CE, Stout JC, Kiecolt-Glaser JK. Stress depresses interferon production by leukocytes concomitant with a decrease in natural killer cell activity. Behav Neurosci. 1986;100:675-8.

Hanahan D, Weinberg RA. Hallmarks of cancer: the next generation. Cell. 2011;144:646-74.

Herberman R, Ortaldo J, Riccardi C. Interferon and NK cells. In: Merigan TC, Friedman RM, editors. Interferons. London: Academic Press; 1982. p. 287-94.

Herberman RB, Ortaldo JR. Natural killer cells: their role in defenses against disease. Science. 1981;214:24-30.

Hunzeker J, Padgett DA, Sheridan PA, Dhabhar FS, Sheridan JF. Modulation of natural killer cell activity by restraint stress during an influenza A/PR8 infection in mice. Brain Behav Immun. 2004;18:526-35.

Irwin M, Brown M, Patterson T, Hauger R, Mascovich A, Grant I. Neuropeptide Y and natural killer cell activity: findings in depression and Alzheimer caregiver stress. FASEB J. 1991;5:3100-7

Irwin M, Daniel M, Risch SC, Bloom E, Weiner H. Plasma cortisol and natural killer cell activity during bereavement. Biol Psychiat. 1988;24:173-8.

Kanter P, Leister KJ, Tomei LK, Wenner PA, Wenner CE. Epidermal growth factor and tumor promoters prevent DNA fragmentation by diverent mechanisms. Biochem Biophys Res Commun. 1984;118:393-9.

Kiecolt-Glaser JK, Garner W, Speicher CE, Penn G, Glaser R. Psychosocial modifiers of immunocompetence in medical students. Psychosomat Med. 1984:46:7-14.

Kiecolt-Glaser JK, Glaser R, Strain EC, et al. Modulation of cellular immunity in medical students. J Behav Med. 1986;9:311-20. 29.

Kiecolt-Glaser JK, Glaser R, Williger D, Stout J, Messick G, Sheppard S, et al. Psychosocial enhancement of immunocompetence in a geriatric population. Health Psychol. 1985a;4:25-41. 32.

Kiecolt-Glaser JK, Glaser R. Psychoneuroimmunology: can psychological interventions modulate immunity? J Consult Clin Psychol. 1992;60:569-75.

Kiecolt-Glaser JK, Malarkey WB, Chee M, Newton T, Cacioppo JT, Mao HY, et al. Negative behaviour during marital conflict is associated with immunological down-regulation. Psychosomat Med. 1993;55:395-409.

Kiecolt-Glaser JK, Stephens R, Lipitz P, Speicher CE, Glaser R. Distress and DNA repair in human lymphocytes. J Behav Med. 1985b;8:311-20.

Kinsey SG, Bailey MT, Sheridan JF, Padgett DA, Avitsur R. Repeated social defeat causes increased anxiety-like behavior and alters splenocyte function in C57BL/6 and CD-1 mice. Brain Behav Immun. 2007;21:458-66.

Kossakowska AE, Edwards DR, Prusinkiewicz C, Zhang MC, Guo D, Urbanski SJ, et al. Interleukin-6 regulation of matrix metalloproteinase (MMP-2 and MMP9) and tissue inhibitor of metalloproteinase (TIMP-1) expression in malignant non-Hodgkin's lymphomas. Blood. 1999;94:2080-9.

Kradin R, Rodberg G, Zhao LH, Leary C. Epinephrine yields translocation of lymphocytes to the lung. Exp Mol Pathol. 2001;70:1-6.

Levy SM, Herberman R, Lippman M, d'Angelo T. Correlation of stress factors with sustained depression of natural killer cell activity and predicted prognosis in patients with breast cancer. J Clin Oncol. 1987;5:348-53.

Levy SM, Herberman RB, Maluish AM, Schlien G, Lippman M. Prognostic risk assessment in primary breast cancer by behavioural and immunological parameters. Health Psychol. 1985;4:99-113.

Levy SM, Herberman RB, Whiteside T, Sanzo K, Lee J, Kirkwood J. Perceived social support and tumor estrogen/progesterone receptor status as predictors of natural killer call activity in breast cancer patients. Psychosomat Med. 1990:52:73-85.

Li GY, Yao KT, Glaser R. Sister chromatid exchange and nasopharyngeal carcinoma. Int J Cancer. 1989;43:613-8.

Lillberg K, Verkasalo PK, Kaprio J, Teppo L, Helenius H, Koskenvuo M. Stressful life events and risk of breast cancer in 10,808 women: a cohort study. Am J Epidemiol. 2003;157:415-23.

Marucha PT, Crespin TR, Shelby RA, Andersen BI. TNF-alpha levels in cancer patients relate to social variables. Brain Behav Immun. 2005;19:521-5.

Mays JW, Bailey MT, Hunzeker JT, Powell ND, Papenfuss T, Karlsson EA, et al. Influenza virus-specific immunological memory is enhanced by repeated social defeat. J Immunol. 2010;184:2014-25.

Mays JW, Powell ND, Hunzeker JT, Hanke ML, Bailey MT, Sheridan JF. Stress and the anti-influenza immune response: repeated social defeat augments clonal expansion of CD8(+)T cells during primary influenza A viral infection. J Neuroimmunol. 2012;243:34-42.

Nakaya N. Effect of psychosocial factors on cancer risk and survival. J Epidmiol. 2014;24(1):1-6. 
Page GG, Ben-Eliyahu S, Liebeskind JC. The role of LGL, NK cells in surgeryinduced promotion of metastasis and its attenuation by morphine. Brain Behav Immun. 1994;8:241-50.

Palermo-Neto J, de Oliveira MC, de Robespierre SW. Effects of physical and psychological stressors on behavior, macrophage activity, and Ehrlich tumor growth. Brain Behav Immun. 2003;17:43-54

Pierce BL, Ballard-Barbash R, Bernstein L, Baumgartner RN, Neuhouser ML, Wener $\mathrm{MH}$, et al. Elevated biomarkers of inflammation are associated with reduced survival among breast cancer patients. J Clin Oncol. 2009;27:3437-44.

Powell ND, Bailey MT, Mays JW, Stiner-Jones LM, Hanke ML, Padgett DA, et al. Repeated social defeat activates dendritic cells and enhances toll-like receptor dependent cytokine secretion. Brain Behav Immun. 2009;23:225-31.

Powell ND, Mays JW, Bailey MT, Hanke ML, Sheridan JF. Immunogenic dendritic cells primed by social defeat enhance adaptive immunity to influenza A virus. Brain Behav Immun. 2011;25:46-52.

Reiche EMV, Nunes SOV, Morimoto HK. Stress, depression, the immune system, and cancer. Lancet Oncol. 2004;5:617-25. 62.

Sephton S, Spiegel D. Circadian disruption in cancer: a neuroendocrine-immune pathway from stress to disease? Brain Behav Immun. 2003;17:321-8.

Romano GH, Harari Y, Yehuda T, Pldhorzer A, Rubinstein L, Shamir R, et al. Environmental streses disrupt telomere length homeostasis. PLoS Genet. 2013;9(9):e1003721.

Salgado R, Junius S, Benoy I, Van DP, Vermeulen P, Van ME, et al. Circulating interleukin-6 predicts survival in patients with metastatic breast cancer. Int J Cancer. 2003;103:642-6.

Saul AN, Oberyszyn TM, Daugherty C, Kusewitt D, Jones S, Jewell S, et al. Chronic stress and susceptibility to skin cancer. J Natl Cancer Inst. 2005;97:1760-7.

Schedlowski M, Falk A, Rohne A, Wagner TO, Jacobs R, Tewes U, et al. Catecholamines induce alterations of distribution and activity of human natural killer (NK) cells. J Clin Immunol. 1993;13:344-51.

Setlow RB. Repair deficient human disorders and human cancer. Nature. 1978;271:713-7

Sloan EK, Priceman SJ, Cox BF, Yu S, Pimentel MA, Tangkanangnukul V, et al. The sympathetic nervous system induces a metastatic switch in primary breast cancer. Cancer Res. 2010;70:7042-52.

Sood AK, Bhatty R, Kamat AA, Landen CN, Han L, Thaker PH, et al. Stress hormone-mediated invasion of ovarian cancer cells. Clin Cancer Res. 2006;12:369-75

Spiegel D, Bloom JR, Kraemer HC, Gottheil E. Effect of psychosocial treatment on survival of patients with metastatic breast cancer. Lancet. 1989;2:888-901.

Spiegel D, Kato PM. Psychosocial influences on cancer incidence and progression. Harv Rev Psychiat. 1996;4:10-26. 6.

Spiegel D, Giese-Davis J. Depression and cancer: mechanisms and disease progression. Biol Psychiatry. 2003;54:269-82.

Stark JL, Avitsur R, Hunzeker J, Padgett DA, Sheridan JF. Interleukin-6 and the development of social disruption-induced glucocorticoid resistance. J Neuroimmunol. 2002;124:9-15.

Steplewski Z, Vogel WH, Ehya H, Poropatich C, Smith JM. Effects of restraint stress on inoculated tumor growth and immune response in rats. Cancer Res. 1985:45:5128-33.

Lutgendorf SK, Sood AK. Biobehavioral factors and cancer progression: physiological pathways and mechanisms. Psycosom Med. 2011;73(9):724-30.

Tomei LD, Kanter P, Wenner CE. Inhibition of radiationinduced apoptosis in vitro. Biochem Biophys Res Commun. 1988;155:324-31.

Tomei LD, Kiecolt-Glaser JK, Kennedy S, Glaser R. Psychological stress and phorbol ester inhibition of radiation-induced apoptosis in human PBLs. Psychiat Res. 1990;33:59-71.

Tseng RJ, Padgett DA, Dhabhar FS, Engler H, Sheridan JF. Stress-induced modulation of NK activity during influenza viral infection: role of glucocorticoids and opioids. Brain Behav Immun. 2005;19:153-64.

Uchino BN, Cacioppo JT, Kiecolt-Glaser JK. The relationship between social support and physiological processes: a review with emphasis on underlying mechanisms. Psychol Bull. 1996;119:488-531.

Whiteside TT, Herberman RB. The role of natural killer cells in human disease. Clin Immun Immunopathol. 1989;53:1-23.
Wohleb ES, Hanke ML, Corona AW, Powell ND, Stiner LM, Bailey MT, et al. Beta-adrenergic receptor antagonism prevents anxiety-like behavior and microglial reactivity induced by repeated social defeat. J Neurosci. 2011;31:6277-88.

Yang EV, Sood AK, Chen M, Li Y, Eubank TD, Marsh CB, et al. Norepinephrine upregulates the expression of vascular endothelial growth factor, matrix metalloproteinase (MMP)-2, and MMP-9 in nasopharyngeal carcinoma tumor cells. Cancer Res. 2006;66:10357-64.

\section{Submit your manuscript to a SpringerOpen ${ }^{\odot}$ journal and benefit from:}

- Convenient online submission

Rigorous peer review

- Immediate publication on acceptance

- Open access: articles freely available online

- High visibility within the field

- Retaining the copyright to your article

Submit your next manuscript at $>$ springeropen.com 